\title{
Vitamin D insufficiency is high in Malaysia: A systematic review and meta-analysis of studies on vitamin D status in Malaysia
}

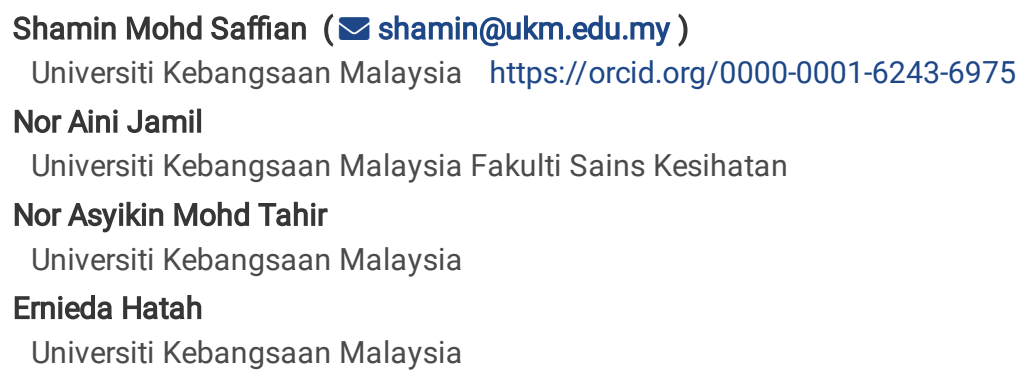




\section{Abstract}

Vitamin D plays an important role in the immune system and many non-communicable diseases. The prevalence of vitamin D deficiency for the overall population of Malaysia is unknown. This study systematically reviewed and pooled studies that report vitamin D status from participants residing in Malaysia. PubMed, Scopus, Web of Science and MyJurnal were searched up to June 2021 without language restrictions. We include studies that reported the 25-hydroxyvitamin D (25(OH)D) concentrations and defined their cut-off for deficiency or insufficiency from healthy participants residing in Malaysia. Random effects model was used to pool vitamin D status using established cut-offs of < $30 \mathrm{nmol} / \mathrm{L},<$ $50 \mathrm{nmol} / \mathrm{L}$, and $<75 \mathrm{nmol} / \mathrm{L}$ according to age group. We identified 203 studies, of which we included 31 studies in the meta-analysis. The pooled proportion for < 30nmol/L was $21 \%(95 \% \mathrm{Cl} 9-36, \mathrm{n}=2,438$ from 10 studies), while the pooled proportion < 50nmol/L was 64\% (95\% Cl 55-72, $\mathrm{n}$ $=13,927$ from 29 studies), and < 75nmol/L was $85 \%$ (95\% Cl 61-100, $\mathrm{n}=1,376$ from 5 studies). Heterogeneity was high ( $\mathrm{I}^{2}$ ranged from $98-$ $99 \%$ ). Higher proportions of vitamin D insufficiency (defined as $<50 \mathrm{nmol} / \mathrm{L}$ ) were found in participants living in the urban areas (compared to rural areas), in females (compared to males), and in Malays and Malaysian Indians (compared to Malaysian Chinese) ethnicities. In conclusion, vitamin D insufficiency is highly prevalent in Malaysia, despite being a country that is close to the equator. We strongly urge prompt public health measures to improve the vitamin D status in Malaysia.

\section{Introduction}

Vitamin D is well recognized as a hormone that plays an essential role in maintaining adequate serum calcium and phosphate concentrations and bone health. The importance of vitamin D in maintaining a good immune system has also been well discussed [1]. Following the coronavirus disease-2019 (COVID-19) pandemic, there has been a renewed interest in understanding the role of vitamin D in managing COVID-19 infection [2]. Several systematic reviews have demonstrated that vitamin D levels are associated with the severity of COVID-19 infections [3-11]. This is echoed by several clinical trials that have shown positive outcomes of supplementing vitamin D in COVID-19 infection, especially in vitamin D deficient patients [8, 12-15]. Although the true benefit of vitamin D in COVID-19 management remains arguable [16-19], the importance of maintaining adequate vitamin $\mathrm{D}$ levels for general health is undeniable.

There is no consensus on the optimal vitamin D concentrations in the body (measured as 25-hydroxyvitamin D; 25(OH)D). It is generally agreed that concentrations $<30 \mathrm{nmol} / \mathrm{L}$ (or $12 \mathrm{ng} / \mathrm{mL}$ ) should be avoided in all age groups [20], but the definition of deficiency and insufficiency varies between guidelines. The Endocrine Society Clinical Practice Guidelines 2011 defines vitamin D deficiency as 25(OH)D concentrations <50nmol/L $(20 \mathrm{ng} / \mathrm{mL})$, while $52.5-72.5 \mathrm{nmol} / \mathrm{L}(21-29 \mathrm{ng} / \mathrm{mL})$ is defined as insufficient [21]. On the other hand, the Institute of Medicine (IOM) defines vitamin D deficiency as $<30 \mathrm{nmol} / \mathrm{L}$, while 30 to $50 \mathrm{nmol} / \mathrm{L}$ is insufficient [22]. Misra et al., 2008, defines vitamin D deficiency as $\leq 37.5 \mathrm{nmol} / \mathrm{L}$ and insufficiency as $37.5-50 \mathrm{nmol} / \mathrm{L}$ [23]. Although there is no consensus on the terminology used, a cut-off of $<50 \mathrm{nmol} / \mathrm{L}$ is commonly used between guidelines. At this concentration, there is activation of compensatory mechanisms to maintain calcium homeostasis, which will affect bone and muscle health [24].

Malaysia is a Southeast Asian country located close to the Equator, with latitudes ranging from $1.2^{\circ} \mathrm{N}$ to $6.8^{\circ} \mathrm{N}$. Malaysia consists of two regions: Peninsular Malaysia, which houses approximately $80 \%$ of the Malaysian population, and Malaysian Borneo. It has an equatorial climate with relatively stable temperatures all year that are hot, sunny, and humid. There is seasonal climate variability closely tied to the drier Southwest Monsoon, which occurs from April to September, and the wetter Northeast Monsoon, from October to March [25]. During periods of heavy rainfall, more of the population may be confined indoors, limiting their sun exposure during the day. However, vitamin D levels were not found to be significantly associated with seasonal changes for indoor workers [26]. Approximately $69.8 \%$ of the 29.9 million Malaysian population is Malay and Bumiputera, $22.4 \%$ is Chinese (i.e., Malaysian Chinese), $6.8 \%$ is Indian (i.e., Malaysian Indian), and the remainder is other ethnicities [27]. Malaysian Chinese generally have fair skin tone, whereas Malays' skin tone may vary from light to tanned, and most Malaysian-Indians have darker skin tone [28]. As vitamin D is synthesized in the skin following sunlight exposure and is highly correlated with skin colour, the Malay and Malaysian Indian populations are at higher risk of lower vitamin D status.

Several studies have investigated the vitamin D status of subpopulations in Malaysia. However, vitamin D status for the overall population of Malaysia is poorly understood. Several review articles have cited single studies to depict the vitamin D status in Malaysia, and those earlier studies indicate that vitamin D deficiency is relatively high compared to other countries [29-31]. Therefore, this study hypothesizes that vitamin D deficiency is prevalent in Malaysia's population. The overarching objective of this study is to pool data from studies that have been conducted on the vitamin D status of Malaysian residents.

\section{Methods}

This systematic review was conducted following the PRISMA guidelines [32] and was registered in PROSPERO (CRD42021260259).

\section{Identifying published studies}


We searched through PubMed, Scopus, Web of Science and MyJurnal (a Malaysian Journal database) from their inception until June 2021. A systematic search was carried out to identify all studies that reported vitamin D status in Malaysian residents. The search terms included (Vitamin D OR its synonyms) AND (Malaysia OR its synonyms). The full record of the search strategy is presented in Appendix Table 3. We did not use any language or other search limits. Key review publications were also identified and searched for further relevant studies. In addition, the reference lists from the identified studies were also examined for potentially relevant studies.

\section{Inclusion and exclusion criteria}

For a study to be included in the systematic review, there were two inclusion criteria: i) the study measured serum 25(OH)D levels in healthy Malaysians and ii) was non-interventional study and conducted either as cross-sectional, case-control, or longitudinal study design. For longitudinal studies, baseline vitamin D levels must be provided. Studies were excluded if they were: i) case reports or case series, or ii) meeting abstracts or unpublished materials.

For case-control studies, only data from healthy population subgroups were considered in the meta-analysis. We excluded studies in population where the lifestyle differed significantly from Malaysia's general population. If a subsequent study included data from a previous cohort of individuals, the study with the larger sample size will be included in the meta-analysis.

Three investigators (NAJ, SMS, NAMT) developed the search strategy. Then, SMS and NAMT performed the database search and independently screened the retrieved articles based on the titles and abstracts. All four authors assessed the full-text articles and selected studies based on the inclusion and exclusion criteria. Any disagreements in the study selection were resolved by consensus. All data were extracted from the selected studies using a standardized extraction form, which included information on the study location, period of data collection, population demographics (ethnicity, sex, age), assay method, vitamin D status (including cut-off definitions), and vitamin D concentrations.

\section{Critical appraisal of studies included}

After considering various quality assessment tools for prevalence studies [33], the Joanna Briggs Institute Prevalence Critical Appraisal Tool, 2014 [34, 35] was used for quality assessment. Three investigators (EMH, NAJ, and SMS) critically appraised and rated the studies included in the meta-analysis using the tool. The tool consists of nine questions with four standard answer options (yes/no/unclear/not applicable). Each rater rated independently; however, discussions were carried out to ensure that any discrepancies were discussed and agreed upon through consensus. Due to the cross-sectional nature of the data used for the meta-analysis, question number 9 of the tool (on response rate) was omitted, giving a maximum of 8 points.

\section{Statistical analysis}

For the overall data, we performed a meta-analysis using predetermined vitamin D cut-off values $(<30 \mathrm{nmol} / \mathrm{L},<50 \mathrm{nmol} / \mathrm{L}$, and $<75$ $\mathrm{nmol} / \mathrm{L}$ ) sub-grouped by age category and a meta-analysis of mean $25(\mathrm{OH}) \mathrm{D}$ levels. The random-effects model was used to pool the proportion and mean values given an a priori assumption of significant heterogeneity between prevalence studies [36]. If the mean and standard deviation were not provided, they were estimated from the median, interquartile range, range, and sample size, assuming that the data were not significantly skewed [37]. For all meta-analyses of specific subgroup proportions (e.g., gender, ethnicity), a cut-off of <50nmol/L was used, in view that this cut-off is present in almost all of the studies. We examined the heterogeneity between studies using the $\mathrm{I}^{2}$ statistics with values of $<25 \%,<50 \%,<75 \%$ indicates low, moderate, and high and the $\chi 2$ test with $\mathrm{P}<0.05$ to denote significance [38]. All analyses were performed using MetaXL, version 5.3 (EpiGear International, Queensland, Australia). A sensitivity analysis is reported automatically by MetaXL by excluding one study at a time and recalculating the pooled effect sizes and the associated heterogeneity statistics. The funnel plot was not used as it is inaccurate to assess publication bias for prevalence studies [39]. The overall mean vitamin D levels and the proportion of vitamin D deficiency/insufficiency were also summarized by study location.

\section{Results}

\section{Literature search results and characteristics of the eligible studies}

From the 203 articles screened, 43 full-text articles were assessed, with 33 of them included in this study (see Fig. 1). Table 1 shows the characteristics of the studies included in the systematic review. Only two studies were published prior to 2010 [40, 41]. Twenty-four studies were 
mainly from participants in the capital city of Malaysia (Kuala Lumpur and its surrounding areas). Four studies were excluded as they only presented data on specific patients and did not include healthy controls [42-45].

One study on indigenous people was excluded from the meta-analysis in view that their lifestyles differ significantly from the rest of the population [46]. Two studies were excluded from the meta-analysis on the basis that it has part of the same individuals from a previous study

$[47,48]$. The summary of study quality assessment is presented in Appendix Table 4). All of the included studies measured 25(OH)D levels using immunoassays, except for four studies that used chromatographic methods [49-52].

\section{Meta-analyses}

For the $<30 \mathrm{nmol} / \mathrm{L}$ cut-off, 10 studies with a total of 2,438 participants were included. The pooled proportion for this cut-off was $21 \%$ (95\% Cl $9-$ $36 \%$, see Fig. 2). Pregnant women had a higher proportion of participants with 25(OH)D levels $<30 \mathrm{nmol} / \mathrm{L}(\mathrm{n}=613,40 \%)$.

All studies eligible for the meta-analysis, except for two studies [53, 54], had a <50nmol/L cut-off. The pooled proportion for <50nmol/L from 29 studies with data from 13,927 individuals was $63.9 \%$ (95\% Cl 55.3-72.1, see Fig. 3). Again, pregnant women represent the highest proportion with vitamin D levels of $<50 \mathrm{nmol} / \mathrm{L}$. The pooled proportion for each subgroup of participants was above $50 \%$ except for one study [55]. Mat et. al [55] conducted a study on adults above 55 years old, and 203 out of the 1,011 participants were taking vitamin D supplements, which could explain the lower proportion of individuals with levels $<50 \mathrm{nmol} / \mathrm{L}$.

Only 5 studies with 1,376 participants reported a cut-off of $<75 \mathrm{nmol} / \mathrm{L}$, and the pooled proportion was $85 \%$ (95\% Cl $61-100$, see Fig. 4 ). All pooled proportions, including most subgroups, were considered high, indicating substantial heterogeneity $(>99 \%)$.

The pooled mean $(95 \% \mathrm{Cl})$ according to the location of the study is reported in Fig. 5. Not surprisingly, the urban population had a higher proportion of vitamin D insufficiency $(66 \%, 95 \% \mathrm{Cl} 56.9-75, \mathrm{n}=10,843)$ compared to the rural population $(45.6 \%, 95 \% \mathrm{Cl} 21-71.1$, $\mathrm{n}=3487$ ), respectively (see Appendix Fig. 6 and Fig. 7). Chua et al., 2020 [46] conducted a study on the indigenous population, which is considered a significant outlier and was thus excluded from the meta-analysis. However, Chua et al. reported that only $1.4 \%$ (out of 555 indigenous people) had $25(\mathrm{OH}) \mathrm{D}$ levels $<50 \mathrm{nmol} / \mathrm{L}$, and $26.3 \%$ had levels $<75 \mathrm{nmol} / \mathrm{L}$.

Vitamin D insufficiency is also more common in females (76\%, 95\% Cl 65-86, $n=6,264$, see Appendix Fig. 8) compared to males (46\%, 95\% Cl 25.6-67\%, n=3,664, see Appendix Fig. 9). In terms of ethnicity, Malays (77\%, 95\% Cl 65-87; $n=4,928$, see Appendix Fig. 10) and Indians (77\%, 95\% Cl 57-92; n=768, see Appendix Fig. 11) had higher proportions of vitamin D insufficiency than the Chinese population (34.5\%, 95\%Cl 17-54; $\mathrm{n}=1,353$, see Appendix Fig. 12). Only one study examined the relationship between monsoon seasonality and vitamin $\mathrm{D}$ status and found no significant association [26].

\section{Discussion}

This study found that vitamin D deficiency, as defined by three cut-offs, is common in Malaysia. Precisely, over half of the population is estimated to have 25(OH)D levels $<50 \mathrm{nmol} / \mathrm{L}$ (see Fig. 3). Only two studies $[40,41]$ were conduct prior to 2010 , and the majority were studies within the past five years, indicating that the data would reflect the current situation. However, all of the studies reported data collected before the COVID-19 pandemic. COVID-19 pandemic-related confinement has been shown to worsen vitamin D status in several studies outside of Malaysia $[56,57]$. Vitamin D deficiency was still detected in the indigenous population, whose lifestyle would involve more outdoor activities and sun exposure. However, the proportion is very much lower than that of the general Malaysian population [46]. It should be noted that there was substantial heterogeneity between the studies, which could partly be explained by age group, living in urban areas, gender, and ethnicity. Pregnant women were at a much higher risk of vitamin D deficiency than all other age groups for all cut-offs. A longitudinal study followed 179 pregnant women from early pregnancy to birth found that at early pregnancy, $89 \%$ had levels $<50 \mathrm{nmol} / \mathrm{L}$, and this rose to $96.1 \%$ at birth [52]. Although $11.1 \%$ took vitamin D supplements, none of the women had sufficient vitamin D status at birth.

Our study indicates that vitamin D deficiency/insufficiency in Malaysia can be considered very high compared to other regions worldwide. Table 2 is adapted and updated from a commentary on reviews or systematic reviews of vitamin $D$ status for a country or continent by Bouillon, $R$ (2020) [24]. Vitamin D levels $<30 \mathrm{nmol} / \mathrm{L}$ in Malaysia are approximately equal to the African continent, but the proportion of levels $<50 \mathrm{nmol} / \mathrm{L}$ is much higher. However, the prevalence for both cut-offs is comparable to estimates from Mainland China [58]. It is also interesting to note that Malaysian Chinese have a much lower proportion of vitamin D insufficiency $(35 \%<50 \mathrm{nmol} / \mathrm{L})$ compared to Chinese from Mainland China. We are not aware of any studies exploring the difference between Chinese in different geographical regions and their vitamin $\mathrm{D}$ status.

The prevalence of vitamin D deficiency could be correlated to the prevalence of several non-communicable diseases in Malaysia. It has been shown that obese individuals have lower vitamin D levels compared to non-obese subjects [65] due to the reduced bioavailability of the fatsoluble vitamin D [66]. According to Malaysia's National Health and Morbidity Survey 2019, approximately half of Malaysians were above the

Page 4/17 
ideal body weight, with $30.4 \%$ overweight and $19.7 \%$ obese [67]. Vitamin D deficiency has also been linked to the onset of insulin resistance and diabetes mellitus [68]. The prevalence of diabetes mellitus in Malaysia is increasing at an alarming rate, with the overall prevalence exceeding $18 \%$ in 2019 [69]. In addition, the prevalence of raised blood glucose in individuals with unknown diabetes is even higher at $43.4 \%$ (95\% $\mathrm{Cl}$ 37.37-49.65) among people aged 65-69 years, which can be attributed to a high intake of sugary beverages [67]. In mechanistic animal studies, chronic consumption of high fructose diets can reduce circulating $1,25-(\mathrm{OH})_{2} \mathrm{D}_{3}[70,71]$. In our study, only two studies explored the association of vitamin D status and obesity, but the results were conflicting $[72,73]$. This prompts for more studies exploring the association of vitamin $D$ and metabolic syndrome in Malaysia.

Dietary vitamin D can be obtained by consuming food that naturally contains vitamin D, fortified food, or supplements. However, limited food choices naturally contain vitamin D in the Malaysian diet [74]. Furthermore, vitamin D fortification in Malaysia is voluntary by the manufacturers with only a few fortifying milk for children and adults [74]. The Malaysian Adult Nutrition survey reported that the highest consumer of full cream milk is amongst adults aged 50-59, with only $24 \%$ reported daily consumption, while only $15 \%$ of individuals aged 18 and 19 reported daily consumption [75]. In this meta-analysis, only approximately 10-20\% of the participants take vitamin D supplements [52, 55, 76, 77], although the frequency and dosage of supplementation are unclear.

In the absence of significant dietary sources, Malaysians are left to sunlight exposure to achieve adequate vitamin D levels. However, there are numerous reasons why Malaysians tend to avoid sun exposure. Some of the barriers to sun exposure identified amongst Malay women with low vitamin D status include misunderstanding about vitamin D, health concerns towards sun exposure, including effects on skin colour and surface, weather (hot and rainy), and religious/cultural clothing practices [78]. Additionally, limited studies are investigating the synthesis of vitamin D following sun exposure in Malaysia [79]. Due to the scarcity of studies, it is unclear exactly how long and how much skin surface is required to be exposed to the sun to obtain adequate vitamin D levels in Malaysia. Recommendations are further complicated by different ethnicities with different skin tones and different cultural/religious clothing. Hence, more research on sun exposure in Malaysia to meet adequate vitamin $D$ levels is required to provide more explicit guidelines.

There are several notable limitations in this study. Most studies do not report vitamin D supplementation, although some included this information [80]. However, vitamin D supplementation is not a common practice among the general Malaysian population, and therefore it is unlikely to affect our results significantly. Secondly, 25(OH)D levels were measured using different chromatographic and immunoassays. This is a common issue when comparing studies that involve measurements of vitamin D plasma levels as there is no worldwide standardization [81]. Nevertheless, in Mogire's study [63], different vitamin D assays accounted for only $5 \%$ of the heterogeneity and had no significant impact on the overall 25(OH)D mean concentrations estimate. Thirdly, most of the studies included in the meta-analysis used simple random sampling, which is prone to bias. Finally, although we tried to be inclusive by having a broad inclusion and minimal exclusion criteria, there were limited data for many states in Malaysia.

\title{
Conclusion
}

Malaysia has a high prevalence of vitamin D deficiency and insufficiency, with more than half of the population estimated to have levels $<50 \mathrm{nmol} / \mathrm{L}$. Vitamin D deficiency is more prevalent in Malay and Malaysian Indian ethnic groups than in Malaysian Chinese. Female gender has lower vitamin D levels compared to male. All of the data included in the study were collected prior to the COVID-19 pandemic, in which confinement was not common practice. As a result, these findings are likely to be an underestimation of the current situation. We strongly recommend immediate public health measures such as the refinement of nutritional guidelines, development of government policies and awareness campaigns to improve vitamin D status in Malaysia.

\section{Declarations}

Conflicts of interest: The authors have no relevant financial or non-financial interests to disclose.

\author{
Funding: No funding was received for conducting this study.
}




\section{References}

1. Prietl B, Treiber G, Pieber TR, Amrein K. Vitamin D and immune function. Nutrients. 2013;5(7):2502-21. doi:10.3390/nu5072502.

2. Shah Alam M, Czajkowsky DM, Aminul Islam M, Ataur Rahman M. The role of vitamin D in reducing SARS-CoV-2 infection: An update. Int Immunopharmacol. 2021;97:107686. doi:10.1016/j.intimp.2021.107686.

3. Petrelli F, Luciani A, Perego G, Dognini G, Colombelli PL, Ghidini A. Therapeutic and prognostic role of vitamin D for COVID-19 infection: A systematic review and meta-analysis of 43 observational studies. J Steroid Biochem Mol Biol. 2021;211:105883. doi:10.1016/j.jsbmb.2021.105883.

4. Wang Z, Joshi A, Leopold K, et al. Association of vitamin D deficiency with COVID-19 infection severity: Systematic review and metaanalysis. Clin Endocrinol (Oxf). 2021. doi:10.1111/cen.14540.

5. Teshome A, Adane A, Girma B, Mekonnen ZA. The Impact of Vitamin D Level on COVID-19 Infection: Systematic Review and Meta-Analysis. Front Public Health. 2021;9:624559. doi:10.3389/fpubh.2021.624559.

6. Shah K, Saxena D, Mavalankar D. Vitamin D supplementation, COVID-19 and disease severity: a meta-analysis. QJM. 2021;114(3):175-81. doi:10.1093/qjmed/hcab009.

7. Rawat D, Roy A, Maitra S, Shankar V, Khanna P, Baidya DK. Vitamin D supplementation and COVID-19 treatment: A systematic review and meta-analysis. Diabetes Metab Syndr. 2021;15(4):102189. doi:10.1016/j.dsx.2021.102189.

8. Pal R, Banerjee M, Bhadada SK, Shetty AJ, Singh B, Vyas A. Vitamin D supplementation and clinical outcomes in COVID-19: a systematic review and meta-analysis. J Endocrinol Invest. 2021. doi:10.1007/s40618-021-01614-4.

9. Jayawardena R, Jeyakumar DT, Francis TV, Misra A. Impact of the vitamin D deficiency on COVID-19 infection and mortality in Asian countries. Diabetes Metab Syndr. 2021;15(3):757-64. doi:10.1016/j.dsx.2021.03.006.

10. Bassatne A, Basbous M, Chakhtoura M, El Zein O, Rahme M, El-Hajj Fuleihan G. The link between COVID-19 and VItamin D (VIVID): A systematic review and meta-analysis. Metabolism. 2021;119. doi:10.1016/j.metabol.2021.154753.

11. Pereira M, Dantas Damascena A, Galvao Azevedo LM, de Almeida Oliveira T, da Mota Santana J. Vitamin D deficiency aggravates COVID19: systematic review and meta-analysis. Crit Rev Food Sci Nutr. 2020:1-9. doi:10.1080/10408398.2020.1841090.

12. Annweiler G, Corvaisier M, Gautier J, et al. Vitamin D Supplementation Associated to Better Survival in Hospitalized Frail Elderly COVID-19 Patients: The GERIA-COVID Quasi-Experimental Study. Nutrients. 2020;12(11). doi:10.3390/nu12113377.

13. Rastogi A, Bhansali A, Khare N, et al. Short term, high-dose vitamin D supplementation for COVID-19 disease: a randomised, placebocontrolled, study (SHADE study). Postgrad Med J. 2020. doi:10.1136/postgradmedj-2020-139065.

14. Annweiler C, Hanotte B, Grandin de l'Eprevier C, Sabatier JM, Lafaie L, Célarier T. Vitamin D and survival in COVID-19 patients: A quasiexperimental study. J Steroid Biochem Mol Biol. 2020;204:105771. doi:10.1016/j.jsbmb.2020.105771.

15. Entrenas Castillo M, Entrenas Costa LM, Vaquero Barrios JM, et al. Effect of calcifediol treatment and best available therapy versus best available therapy on intensive care unit admission and mortality among patients hospitalized for COVID-19: A pilot randomized clinical study. The Journal of Steroid Biochemistry Molecular Biology. 2020;203:105751. doi:https://doi.org/10.1016/j.jsbmb.2020.105751.

16. Smolders J, van den Ouweland J, Geven C, Pickkers P, Kox M. Letter to the Editor: Vitamin D deficiency in COVID-19: Mixing up cause and consequence. Metabolism-Clinical and Experimental. 2021;115.

17. Murai IH, Fernandes AL, Sales LP, et al. Effect of a Single High Dose of Vitamin D3 on Hospital Length of Stay in Patients With Moderate to Severe COVID-19: A Randomized Clinical Trial. Jama. 2021;325(11):1053-60. doi:10.1001/jama.2020.26848.

18. Leaf DE, Ginde AA. Vitamin D3 to Treat COVID-19: Different Disease, Same Answer. JAMA. 2021;325(11):1047-8. doi:10.1001/jama.2020.26850.

19. Rubin R. Sorting Out Whether Vitamin D Deficiency Raises COVID-19 Risk. JAMA. 2021;325(4):329-30. doi:10.1001/jama.2020.24127.

20. Bouillon R. Comparative analysis of nutritional guidelines for vitamin D. Nat Rev Endocrinol. 2017;13(8):466-79. doi:10.1038/nrendo.2017.31.

21. Holick MF, Binkley NC, Bischoff-Ferrari HA, et al. Evaluation, Treatment, and Prevention of Vitamin D Deficiency: an Endocrine Society Clinical Practice Guideline. The Journal of Clinical Endocrinology Metabolism. 2011;96(7):1911-30. doi:10.1210/jc.2011-0385.

22. Institute of Medicine Committee to Review Dietary Reference Intakes for. Vitamin D. Calcium. The National Academies Collection: Reports funded by National Institutes of Health. In: Ross AC, Taylor CL, Yaktine AL, Del Valle HB, editors. Dietary Reference Intakes for Calcium and Vitamin D. Washington (DC): National Academies Press (US) Copyright @ 2011, National Academy of Sciences.; 2011. 
23. Misra M, Pacaud D, Petryk A, Collett-Solberg PF, Kappy M. Vitamin D Deficiency in Children and Its Management: Review of Current Knowledge and Recommendations. Pediatrics. 2008;122(2):398. doi:10.1542/peds.2007-1894.

24. Bouillon R. Vitamin D status in Africa is worse than in other continents. The Lancet Global Health. 2020;8(1):e20-e1. doi:10.1016/s2214$109 \times(19) 30492-9$

25. Kwan MS, Tangang FT, Juneng L. Projected changes of future climate extremes in Malaysia. Sains Malaysiana. 2013;42(8):1051-9.

26. Aris N, Mitra AK, Wan Mohamed WMI, Wan Muda WAM, Jan Mohamed HJ. Effects of occupational sunlight exposure and monsoon season on vitamin D concentration among outdoor and indoor workers in Malaysia. Malaysian Journal of Nutrition. 2020;26(3):425-39. doi:10.31246/mjn-2020-0038.

27. Demographic Statistics Second Quarter. 2021, Malaysia. https://www.dosm.gov.my/v1/index.php? $\mathrm{r}=$ column/cthemeByCat\&cat=430\&bul_id=eGtwdjd4amZJb1JmcFFkYXBKNHg3dz09\&menu_id=LOpheU43NWJwRWVSZkIWdzQ4TIhUUT09.

28. Isa ZM, Shamsuddin K, Bukhari NBI, et al. The reliability of Fitzpatrick skin type chart comparing to mexameter (mx 18) in measuring skin color among first trimester pregnant mothers in Petaling district, Malaysia. Malaysian Journal of Public Health Medicine. 2016;3:59-65.

29. Arabi A, El Rassi R, El-Hajj Fuleihan G. Hypovitaminosis D in developing countries-prevalence, risk factors and outcomes. Nat Rev Endocrinol. 2010;6(10):550-61. doi:10.1038/nrendo.2010.146.

30. Lips P. Vitamin D status and nutrition in Europe and Asia. J Steroid Biochem Mol Biol. 2007;103(3-5):620-5. doi:10.1016/j.jsbmb.2006.12.076.

31. Lim SK, Kung AW, Sompongse S, Soontrapa S, Tsai KS. Vitamin D inadequacy in postmenopausal women in Eastern Asia. Curr Med Res Opin. 2008;24(1):99-106. doi:10.1185/030079908x253429.

32. Liberati A, Altman DG, Tetzlaff J, et al. The PRISMA statement for reporting systematic reviews and meta-analyses of studies that evaluate health care interventions: explanation and elaboration. J Clin Epidemiol. 2009;62(10):e1-34. doi:10.1016/j.jclinepi.2009.06.006.

33. Migliavaca CB, Stein C, Colpani V, Munn Z, Falavigna M. Quality assessment of prevalence studies: a systematic review. J Clin Epidemiol. 2020;127:59-68. doi:10.1016/j.jclinepi.2020.06.039.

34. Munn Z, Moola S, Riitano D, Lisy K. The development of a critical appraisal tool for use in systematic reviews addressing questions of prevalence. International journal of health policy management. 2014;3(3):123.

35. Munn Z, Moola S, Lisy K, Riitano D, Tufanaru C. Methodological guidance for systematic reviews of observational epidemiological studies reporting prevalence and cumulative incidence data. Int J Evid Based Healthc. 2015;13(3):147-53.

36. Barendregt JJ, Doi SA, Lee YY, Norman RE, Vos T. Meta-analysis of prevalence. J Epidemiol Community Health. 2013;67(11):974-8. doi:10.1136/jech-2013-203104.

37. Wan X, Wang W, Liu J, Tong T. Estimating the sample mean and standard deviation from the sample size, median, range and/or interquartile range. BMC Med Res Methodol. 2014;14(1):135. doi:10.1186/1471-2288-14-135.

38. Higgins JP, Thompson SG, Deeks JJ, Altman DG. Measuring inconsistency in meta-analyses. Bmj. 2003;327(7414):557-60. doi:10.1136/bmj.327.7414.557.

39. Hunter JP, Saratzis A, Sutton AJ, Boucher RH, Sayers RD, Bown MJ. In meta-analyses of proportion studies, funnel plots were found to be an inaccurate method of assessing publication bias. J Clin Epidemiol. 2014;67(8):897-903. doi:10.1016/j.jclinepi.2014.03.003.

40. Rahman SA, Chee WS, Yassin Z, Chan SP. Vitamin D status among postmenopausal Malaysian women. Asia Pac J Clin Nutr. 2004;13(3):255-60.

41. Green TJ, Skeaff CM, Rockell JE, et al. Vitamin D status and its association with parathyroid hormone concentrations in women of childbearing age living in Jakarta and Kuala Lumpur. Eur J Clin Nutr. 2008;62(3):373-8. doi:10.1038/sj.ejcn.1602696.

42. Fong CY, Kong AN, Poh BK, et al. Vitamin D deficiency and its risk factors in Malaysian children with epilepsy. Epilepsia. 2016;57(8):1271-9. doi:10.1111/epi.13443.

43. Kong AN, Fong CY, Ng CC, et al. Association of common genetic variants with vitamin D status in Malaysian children with epilepsy. Seizure. 2020;79:103-11. doi:10.1016/j.seizure.2020.05.009.

44. Lee WS, Jalaludin MY, Wong SY, Ong SY, Foo HW, Ng RT. Vitamin D non-sufficiency is prevalent in children with chronic liver disease in a tropical country. Pediatr Neonatol. 2019;60(1):12-8. doi:10.1016/j.pedneo.2018.03.011.

45. Fong CY, Ong FN, Ong LC, Khoo TB, Lee ML. Vitamin D deficiency and insufficiency in Malaysian children with spina bifida. Spinal Cord. 2020;58(9):1030-6. doi:10.1038/s41393-020-0441-7.

46. Chua EY, Mohd Shariff Z, Sulaiman N, Appannah G, Yong HY. Associations of Serum 25-Hydroxyvitamin D with Adiposity and At-Risk Lipid Profile Differ for Indigenous (Orang Asli) Male and Female Adults of Peninsular Malaysia. Int J Environ Res Public Health. 2020;17(8). doi:10.3390/ijerph17082855.

47. Moy FM. Vitamin D status and its associated factors of free living Malay adults in a tropical country, Malaysia. J Photochem Photobiol B. 2011;104(3):444-8. doi:10.1016/j.jphotobiol.2011.05.002. 
48. Poh BK, Rojroongwasinkul N, Nguyen BK, et al. 25-hydroxy-vitamin D demography and the risk of vitamin D insufficiency in the South East Asian Nutrition Surveys (SEANUTS). Asia Pac J Clin Nutr. 2016;25(3):538-48. doi:10.6133/apjcn.092015.02.

49. Ralph AP, Rashid Ali MRS, William T, et al. Vitamin D and activated vitamin D in tuberculosis in equatorial Malaysia: a prospective clinical study. BMC Infect Dis. 2017;17(1):312. doi:10.1186/s12879-017-2314-Z.

50. Lee CL, Ng BK, Wu LL, Cheah FC, Othman H, Ismail NAM. Vitamin D deficiency in pregnancy at term: risk factors and pregnancy outcomes. Horm Mol Biol Clin Investig. 2017;31(3). doi:10.1515/hmbci-2017-0005.

51. Jan Mohamed HJ, Rowan A, Fong B, Loy SL. Maternal serum and breast milk vitamin D levels: findings from the Universiti Sains Malaysia Pregnancy Cohort Study. PLoS One. 2014;9(7):e100705. doi:10.1371/journal.pone.0100705.

52. Mustapa Kamal Basha MA, Abdul Majid H, Razali N, Abd Rashed A, Muhammad H, Yahya A. Longitudinal Vitamin D Deficiency Among Malaysian Pregnant Women and Its Correlation With Neonatal Serum 25-Hydroxyvitamin D Levels. Front Public Health. 2021;9:654292. doi:10.3389/fpubh.2021.654292.

53. Woon FC, Chin YS, Ismail IH, et al. Maternal Vitamin D Levels during Late Pregnancy and Risk of Allergic Diseases and Sensitization during the First Year of Life-A Birth Cohort Study. Nutrients. 2020;12(8). doi:10.3390/nu12082418.

54. Hussain S, Elnajeh M. Prevalence and Risk Factors for Hypovitaminosis D among Healthy Adolescents in Kota Bharu, Kelantan. J ASEAN Fed Endocr Soc. 2020;35(2):176-80. doi:10.15605/jafes.035.02.05.

55. Mat S, Jaafar MH, Sockalingam S, et al. Vitamin D deficiency is associated with ethnicity and knee pain in a multi-ethnic South-East Asian nation: Results from Malaysian Elders Longitudinal Research (MELoR). Int J Rheum Dis. 2018;21(5):930-6. doi:10.1111/1756-185x.13279.

56. Yu L, Ke HJ, Che D, Luo SL, Guo Y, Wu JL. Effect of Pandemic-Related Confinement on Vitamin D Status Among Children Aged 0-6 Years in Guangzhou, China: A Cross-Sectional Study. Risk Manag Healthc Policy. 2020;13:2669-75. doi:10.2147/RMHP.S282495.

57. Dhatt SS, Kumar V, Neradi D, Sodavarapu P, Meetei TT, Goni V. Need for Testing and Supplementation of Vitamin D3 After Release of COVID19 Lockdown in Patients with Increased Musculoskeletal Pain. Indian J Orthop. 2021:1-4. doi:10.1007/s43465-021-00376-8.

58. Liu W, Hu J, Fang Y, Wang P, Lu Y, Shen N. Vitamin D status in Mainland of China: A systematic review and meta-analysis. EClinicalMedicine. 2021;38:101017. doi:10.1016/j.eclinm.2021.101017.

59. Hilger J, Friedel A, Herr R, et al. A systematic review of vitamin D status in populations worldwide. Br J Nutr. 2014;111(1):23-45. doi:10.1017/S0007114513001840.

60. Herrick KA, Storandt RJ, Afful J, et al. Vitamin D status in the United States, 2011-2014. Am J Clin Nutr. 2019;110(1):150-7. doi:10.1093/ajen/nqz037.

61. Cashman KD, Dowling KG, Škrabáková Z, et al. Vitamin D deficiency in Europe: pandemic? The American journal of clinical nutrition. 2016;103(4):1033-44. doi:10.3945/ajcn.115.120873.

62. Durazo-Arvizu RA, Camacho P, Bovet P, et al. 25-Hydroxyvitamin D in African-origin populations at varying latitudes challenges the construct of a physiologic norm. Am J Clin Nutr. 2014;100(3):908-14. doi:10.3945/ajcn.113.066605.

63. Mogire RM, Mutua A, Kimita W, et al. Prevalence of vitamin D deficiency in Africa: a systematic review and meta-analysis. The Lancet Global Health. 2020;8(1):e134-e42. doi:10.1016/s2214-109x(19)30457-7.

64. Zhang W, Stoecklin E, Eggersdorfer M. A glimpse of vitamin D status in Mainland China. Nutrition. 2013;29(7-8):953-7. doi:10.1016/j.nut.2013.01.010.

65. Pereira-Santos M, Costa PR, Assis AM, Santos CA, Santos DB. Obesity and vitamin D deficiency: a systematic review and meta-analysis. Obes Rev. 2015;16(4):341-9. doi:10.1111/obr.12239.

66. Wortsman J, Matsuoka LY, Chen TC, Lu Z, Holick MF. Decreased bioavailability of vitamin D in obesity. Am J Clin Nutr. 2000;72(3):690-3. doi:10.1093/ajcn/72.3.690.

67. IPH. National Health \& Morbidity Survey. (NHMS 2019) Technical Report 2019 Volume I, NCDs - Non-Communicable Diseases: Risk Factors and other Health Problems https://iku.gov.my/images/IKU/Document/REPORT/NHMS2019/Report_NHMS2019-NCD_v2.pdf.

68. Berridge MJ. Vitamin D deficiency and diabetes. Biochem J. 2017;474(8):1321-32. doi:10.1042/bcj20170042.

69. National Diabetes Registry Report 2013-2019. Institute for Public Health National Health and Morbidity Survey 2014. Malaysian Adult Nutrition Survey (MANS). Putrajaya: Ministry of Health Malaysia;

https://www2.moh.gov.my/index.php/database_stores/attach_download/554/80.

70. Douard V, Patel C, Lee J, et al. Chronic high fructose intake reduces serum 1,25 (OH)2D3 levels in calcium-sufficient rodents. PLoS One. 2014;9(4):e93611. doi:10.1371/journal.pone.0093611.

71. Douard V, Sabbagh Y, Lee J, et al. Excessive fructose intake causes 1,25-(OH)(2)D(3)-dependent inhibition of intestinal and renal calcium transport in growing rats. Am J Physiol Endocrinol Metab. 2013;304(12):E1303-13. doi:10.1152/ajpendo.00582.2012.

72. Rahmadhani R, Zaharan NL, Mohamed Z, Moy FM, Jalaludin MY. The associations between VDR Bsml polymorphisms and risk of vitamin D deficiency, obesity and insulin resistance in adolescents residing in a tropical country. PLoS One. 2017;12(6):e0178695. 
doi:10.1371/journal.pone.0178695.

73. Moy F-M, Bulgiba A. High prevalence of vitamin D insufficiency and its association with obesity and metabolic syndrome among Malay adults in Kuala Lumpur, Malaysia. BMC Public Health. 2011;11(1):735. doi:10.1186/1471-2458-11-735.

74. National Coordinating Committee on Food and Nutrition Ministry of Health Malaysia. Recommended Nutrient Intakes for Malaysia 2017, A Report of the Technical Working Group on Nutritional Guidelines http://nutrition.moh.gov.my/wp-content/uploads/penerbitan/buku/RNI.pdf.

75. Norimah AK Jr, Safiah M, Jamal K, et al. Food Consumption Patterns: Findings from the Malaysian Adult Nutrition Survey (MANS). Malays J Nutr. 2008;14(1):25-39.

76. Jamil NA, Shahudin NN, Abdul Aziz NS, et al. Knowledge, Attitude and Practice Related to Vitamin D and Its Relationship with Vitamin D Status among Malay Female Office Workers. Int J Environ Res Public Health. 2019;16(23). doi:10.3390/ijerph16234735.

77. Bukhary NBI, Isa ZM, Shamsuddin K, et al. Risk factors for antenatal hypovitaminosis D in an urban district in Malaysia. BMC Pregnancy Childbirth. 2016;16(1):156. doi:10.1186/s12884-016-0939-3.

78. Shahudin NN, Sameeha MJ, Mat Ludin AF, Manaf ZA, Chin KY, Jamil NA. Barriers towards Sun Exposure and Strategies to Overcome These Barriers in Female Indoor Workers with Insufficient Vitamin D: A Qualitative Approach. Nutrients. 2020;12(10). doi:10.3390/nu12102994.

79. Jamil NA, Yew MH, Noor Hafizah Y, Gray SR, Poh BK, Macdonald HM. Estimated vitamin D synthesis and dietary vitamin D intake among Asians in two distinct geographical locations (Kuala Lumpur, 3 degrees N v. Aberdeen, 57 degrees N) and climates. Public Health Nutr. 2018;21(17):3118-24. doi:10.1017/S1368980018002057.

80. Ariffin MASM, Fazil FN, Yassin NM, et al. Prevalence of Vitamin D Deficiency and its Associated Risk Factors during Early Pregnancy in a Tropical Country: A Pilot Study. Journal of Clinical Diagnostic Research. 2018. doi:10.7860/jcdr/2018/36585.12104.

81. Altieri B, Cavalier E, Bhattoa HP, et al. Vitamin D testing: advantages and limits of the current assays. Eur J Clin Nutr. 2020;74(2):231-47. doi:10.1038/s41430-019-0553-3.

82. Khor GL, Chee WS, Shariff ZM, et al. High prevalence of vitamin D insufficiency and its association with BMI-for-age among primary school children in Kuala Lumpur, Malaysia. BMC Public Health. 2011;11:95. doi:10.1186/1471-2458-11-95.

83. Hawa M, Sakinah H, Hermizi H. Calcium and Vitamin D Status of Kelantanese Malay Women from Low Income Family: A Population-Based Study. Journal of Aging Research Clinical Practice. 2013;2(2):191-6.

84. Nurbazlin M, Chee WS, Rokiah P, et al. Effects of sun exposure on 25(OH) vitamin D concentration in urban and rural women in Malaysia. Asia Pac J Clin Nutr. 2013;22(3):391-9. doi:10.6133/apjcn.2013.22.3.15.

85. Poh BK, Ng BK, Siti Haslinda MD, et al. Nutritional status and dietary intakes of children aged 6 months to 12 years: findings of the Nutrition Survey of Malaysian Children (SEANUTS Malaysia). Br J Nutr. 2013;110(Suppl 3):21-35. doi:10.1017/S0007114513002092.

86. Chin KY, Ima-Nirwana S, Ibrahim S, Mohamed IN, Wan Ngah WZ. Vitamin D status in Malaysian men and its associated factors. Nutrients. 2014;6(12):5419-33. doi:10.3390/nu6125419.

87. Al-Sadat N, Majid HA, Sim PY, et al. Vitamin D deficiency in Malaysian adolescents aged 13 years: findings from the Malaysian Health and Adolescents Longitudinal Research Team study (MyHeARTs). BMJ Open. 2016;6(8):e010689. doi:10.1136/bmjopen-2015-010689.

88. Shafinaz IS, Moy FM. Vitamin D level and its association with adiposity among multi-ethnic adults in Kuala Lumpur, Malaysia: a cross sectional study. BMC Public Health. 2016;16:232. doi:10.1186/s12889-016-2924-1.

89. Moy FM, Hoe VC, Hairi NN, Vethakkan SR, Bulgiba A. Vitamin D deficiency and depression among women from an urban community in a tropical country. Public Health Nutr. 2017;20(10):1844-50. doi:10.1017/S1368980016000811.

90. Quah SW, Abdul Majid H, Al-Sadat N, Yahya A, Su TT, Jalaludin MY. Risk factors of vitamin D deficiency among 15-year-old adolescents participating in the Malaysian Health and Adolescents Longitudinal Research Team Study (MyHeARTs). PLoS One. 2018;13(7):e0200736. doi:10.1371/journal.pone.0200736.

91. Lee YW, Choon SE, Izham S. Serum 25-hydroxyvitamin D deficiency in malaysian children with severe atopic dermatitis. Med J Malaysia. 2019;74(4):259-65.

92. Abd Aziz NH, Yazid NA, Abd Rahman R, et al. Is First Trimester Maternal 25-Hydroxyvitamin D Level Related to Adverse Maternal and Neonatal Pregnancy Outcomes? A Prospective Cohort Study among Malaysian Women. Int J Environ Res Public Health. 2020;17(9). doi:10.3390/ijerph17093291.

93. Arumugam M, Jamil A, Nor NM, Baseri M, Thevarajah S, Mustafa N. Sun Exposure, Dietary Vitamin D and Vitamin D Status in Adult Atopic Dermatitis: A Case Control Study. Malaysian Journal of Medicine and Health Sciences. 2020;16(1).

94. Ismail NA, Mohamed Ismail NA, Bador KM. Vitamin D in gestational diabetes mellitus and its association with hyperglycaemia, insulin sensitivity and other factors. J Obstet Gynaecol. 2020:1-5. doi:10.1080/01443615.2020.1820462.

95. Leiu KH, Chin YS, Mohd Shariff Z, Arumugam M, Chan YM. High body fat percentage and low consumption of dairy products were associated with vitamin D inadequacy among older women in Malaysia. PLoS One. 2020;15(2):e0228803.

doi:10.1371/journal.pone.0228803.

Page 9/17 
96. Ismail TST, Wong SH, Din MH, Mustapha Z, Haron J, Zun ABB. Correlation of Vitamin D with bone mineral density by dual energy X-ray absorptiometry (DXA) scan among healthy Malay adult. Malaysian Journal of Medicine Health Sciences. 2020;16(2):16-22.

97. Chee WSS, Chang CY, Arasu K, et al. Vitamin D Status Is Associated with Modifiable Lifestyle Factors in Pre-Adolescent Children Living in Urban Kuala Lumpur, Malaysia. Nutrients. 2021;13(7):2175.

\section{Tables}


Table 1 Characteristics of studies included in the systematic review

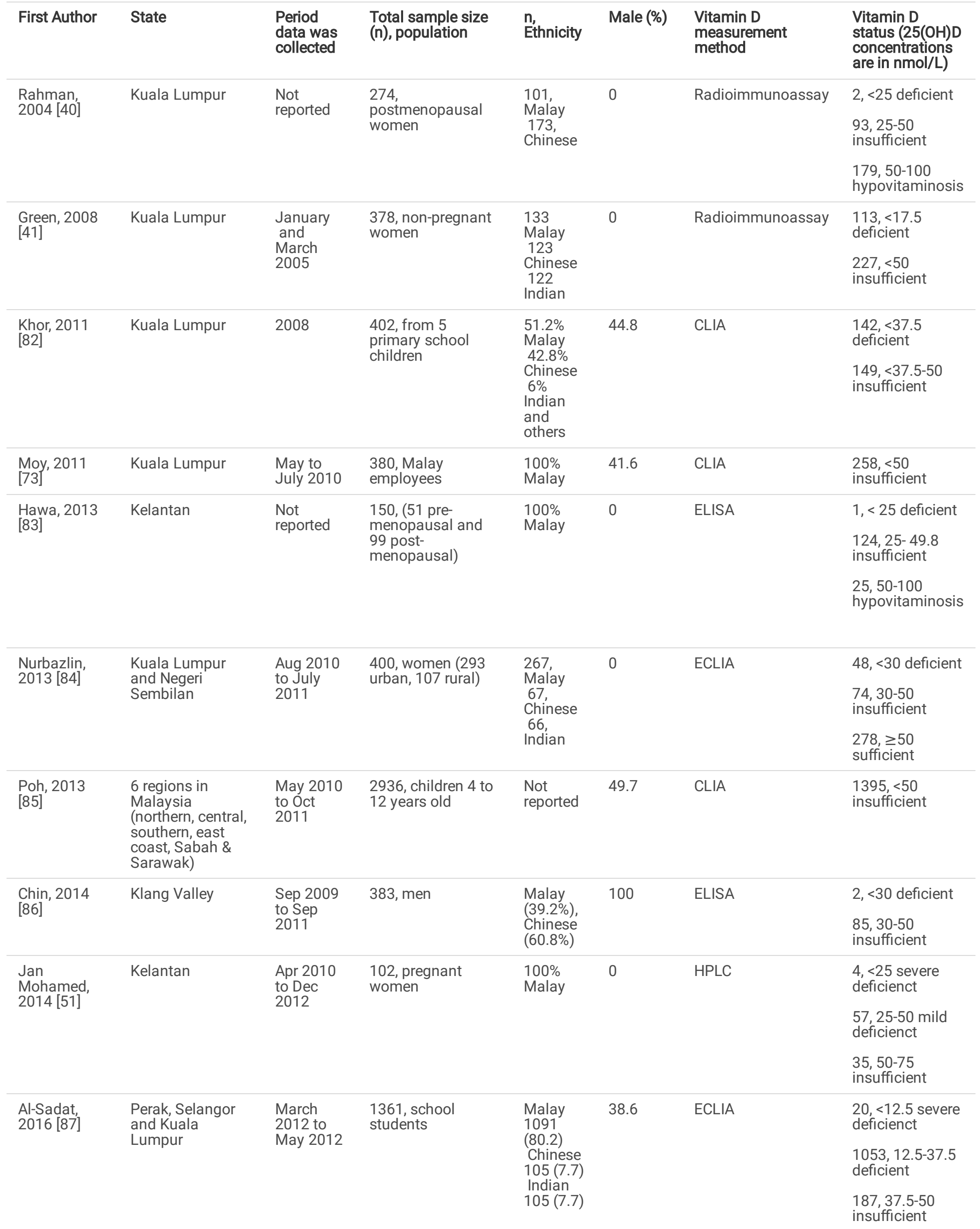




\begin{tabular}{|c|c|c|c|c|c|c|c|}
\hline & & & & $\begin{array}{l}\text { Others } \\
41(3)\end{array}$ & & & \\
\hline \multirow{3}{*}{$\begin{array}{l}\text { Poh, } 2016 \\
{[48]^{\star}}\end{array}$} & \multirow[t]{3}{*}{ Not stated } & \multirow{3}{*}{$\begin{array}{l}2010 \text { to } \\
2011\end{array}$} & \multirow{3}{*}{$\begin{array}{l}\text { 861, children } \\
\text { (subset from Poh } \\
2013 \text { [85]) }\end{array}$} & \multirow{3}{*}{$\begin{array}{l}\text { Not } \\
\text { reported }\end{array}$} & \multirow[t]{3}{*}{53} & \multirow[t]{3}{*}{ CLIA } & $35,<25$ deficient \\
\hline & & & & & & & $\begin{array}{l}341,25-50 \\
\text { insufficient }\end{array}$ \\
\hline & & & & & & & $\begin{array}{l}344,50-75 \\
\text { inadequate }\end{array}$ \\
\hline \multirow[t]{3}{*}{$\begin{array}{l}\text { Shafinaz, } \\
2016[88]\end{array}$} & \multirow[t]{3}{*}{ Kuala Lumpur } & \multirow[t]{3}{*}{$\begin{array}{l}\text { February } \\
\text { to May } \\
2013\end{array}$} & \multirow[t]{3}{*}{$\begin{array}{l}858, \text { teachers from } \\
30 \text { schools }\end{array}$} & $\begin{array}{l}76.9 \% \\
\text { Malay } \\
16.4 \% \\
\text { Chinese }\end{array}$ & \multirow[t]{3}{*}{9.1} & \multirow[t]{3}{*}{ ECLIA } & \multirow[t]{3}{*}{$\begin{array}{l}578,<50 \\
\text { deficient }\end{array}$} \\
\hline & & & & $\begin{array}{l}8.3 \% \\
\text { Indian }\end{array}$ & & & \\
\hline & & & & $\begin{array}{l}0.4 \% \\
\text { Others }\end{array}$ & & & \\
\hline \multirow[t]{4}{*}{$\begin{array}{l}\text { Bukhary, } \\
2016 \text { [77] }\end{array}$} & \multirow[t]{4}{*}{ Selangor } & \multirow{4}{*}{$\begin{array}{l}\text { January } \\
\text { to April } \\
2014\end{array}$} & \multirow{4}{*}{$\begin{array}{l}\text { 396, pregnant } \\
\text { women }\end{array}$} & $\begin{array}{l}77.5 \% \\
\text { Malay }\end{array}$ & \multirow[t]{4}{*}{0} & \multirow[t]{4}{*}{ ECLIA } & \multirow{4}{*}{$\begin{array}{l}174,<24.99 \\
\begin{array}{l}184,25-49.99 \\
\text { deficient }\end{array} \\
33,50-74.99\end{array}$} \\
\hline & & & & $\begin{array}{l}11.2 \% \\
\text { Chinese }\end{array}$ & & & \\
\hline & & & & $\begin{array}{l}8.8 \% \\
\text { Indian }\end{array}$ & & & \\
\hline & & & & $\begin{array}{l}2.5 \% \\
\text { Others }\end{array}$ & & & \\
\hline \multirow[t]{2}{*}{$\begin{array}{l}\text { Lee CL, } \\
2017[50]\end{array}$} & \multirow[t]{2}{*}{ Kuala Lumpur } & \multirow[t]{2}{*}{$\begin{array}{l}\text { Aug } 2013 \\
\text { to Aug } \\
2015\end{array}$} & \multirow{2}{*}{$\begin{array}{l}575, \text { women } \\
\text { completed } 37 \\
\text { weeks of } \\
\text { pregnancy (term) }\end{array}$} & $\begin{array}{l}73.4 \% \\
\text { Malay } \\
18.4 \%\end{array}$ & \multirow[t]{2}{*}{0} & \multirow[t]{2}{*}{ UPLC } & $\begin{array}{l}412,<50 \\
\text { deficient }\end{array}$ \\
\hline & & & & $\begin{array}{l}\text { Chinese } \\
4.9 \% \\
\text { Indian } \\
3.3 \% \\
\text { others }\end{array}$ & & & $\begin{array}{l}121,50-75 \\
\text { insufficient }\end{array}$ \\
\hline $\begin{array}{l}\text { Moy, } 2017 \\
\text { [89] }\end{array}$ & Kuala Lumpur & $\begin{array}{l}\text { March to } \\
\text { Oct } 2013\end{array}$ & $\begin{array}{l}\text { 770, female } \\
\text { teachers }\end{array}$ & $\begin{array}{l}76.6 \% \\
\text { Malay } \\
15 \% \\
\text { Chinese } \\
8.4 \% \\
\text { Indian }\end{array}$ & 0 & ECLIA & $\begin{array}{l}557,<50 \\
\text { deficient }\end{array}$ \\
\hline $\begin{array}{l}\text { Rahmadhani, } \\
2017 \text { [72] }\end{array}$ & Kuala Lumpur & $\begin{array}{l}\text { January } \\
2012 \text { to } \\
\text { July } 2012 .\end{array}$ & $\begin{array}{l}941 \text {, boys and girls } \\
\text { from } 23 \text { schools }\end{array}$ & $\begin{array}{l}75 \% \\
\text { Malay } \\
13 \%\end{array}$ & 28 & ECLIA & $\begin{array}{l}305,<37.5 \\
\text { deficient }\end{array}$ \\
\hline & & & & $\begin{array}{l}\text { Chinese } \\
10 \% \\
\text { Indian } \\
2 \% \\
\text { Others }\end{array}$ & & & $\begin{array}{l}166,37.5-50 \\
\text { insufficient }\end{array}$ \\
\hline $\begin{array}{l}\text { Ralph, } 2017 \\
\text { [49] }\end{array}$ & $\begin{array}{l}\text { Kota Kinabalu, } \\
\text { Sabah }\end{array}$ & $\begin{array}{l}\text { Ethics } \\
\text { approved } \\
\text { in 2010/1 }\end{array}$ & $\begin{array}{l}\text { 92, controls for } \\
\text { cases } \\
\text { (tuberculosis) }\end{array}$ & $\begin{array}{l}\text { Not } \\
\text { reported }\end{array}$ & 35.8 & LCMS & $23,<50$ deficient \\
\hline $\begin{array}{l}\text { Ariffin, } 2018 \\
\text { [80] }\end{array}$ & Kuala Lumpur & $\begin{array}{l}\text { Mar to } \\
\text { Aug } 2017\end{array}$ & $\begin{array}{l}57 \text {, pregnant } \\
\text { women }\end{array}$ & $\begin{array}{l}86 \% \\
\text { Malay }\end{array}$ & 0 & ELISA & $\begin{array}{l}15,<25 \text { severe } \\
\text { deficient }\end{array}$ \\
\hline & & & & $\begin{array}{l}14 \% \text { non- } \\
\text { Malay }\end{array}$ & & & $\begin{array}{l}37,25-49.9 \text { mild } \\
\text { deficient }\end{array}$ \\
\hline $\begin{array}{l}\text { Mat, } 2018 \\
\text { [55] }\end{array}$ & Kuala Lumpur & $\begin{array}{l}\text { November } \\
2013 \text { to } \\
\text { October } \\
2015\end{array}$ & 1011, elderly & $\begin{array}{l}31 \% \\
\text { Malay } \\
36.3 \% \\
\text { Chinese } \\
32.7 \\
\text { Indian }\end{array}$ & 43 & CLIA & $\begin{array}{l}409,<50 \\
\text { deficient }\end{array}$ \\
\hline $\begin{array}{l}\text { Quah, } 2018 \\
\text { [90] }\end{array}$ & $\begin{array}{l}\text { Selangor, Perak } \\
\text { and Kuala }\end{array}$ & $\begin{array}{l}1 \mathrm{Apr} \\
2014 \text { to }\end{array}$ & $\begin{array}{l}\text { 1016, students } \\
(14-15 \text {-year-olds) }\end{array}$ & $\begin{array}{l}\text { Not } \\
\text { reported }\end{array}$ & 38 & CLIA & $338, \leq 50$ \\
\hline & Lumpur & $\begin{array}{l}30 \text { June } \\
2014\end{array}$ & $\begin{array}{l}\text { from } 15 \text { urban and } \\
\text { rural schools }\end{array}$ & & & & $678,>50$ \\
\hline Jamil, 2019 & Kuala Lumpur & March to & 147, Malay office & $100 \%$ & 0 & Enzymatic & $133,<50$ \\
\hline & & & Page 12 & & & & \\
\hline
\end{tabular}




\begin{tabular}{|c|c|c|c|c|c|c|c|}
\hline [76] & & July 2019 & workers & Malay & & Immunoassay & insufficient \\
\hline $\begin{array}{l}\text { Lee YW, } \\
2019 \text { [91] }\end{array}$ & Johor Bahru & $\begin{array}{l}1 \text { st } \\
\text { December } \\
2016 \\
\text { and 31st } \\
\text { May } 2017\end{array}$ & $\begin{array}{l}65, \text { controls for } \\
\text { cases (atopic } \\
\text { dermatitis) }\end{array}$ & $\begin{array}{l}67.7 \% \\
\text { Malay } \\
16.9 \% \\
\text { Chinese } \\
5 \% \\
\text { Indian } \\
\\
5 \% \\
\text { Others }\end{array}$ & 52.3 & ECLIA & $\begin{array}{l}19,<50 \text { deficient } \\
22,50-75 \\
\text { insufficient }\end{array}$ \\
\hline $\begin{array}{l}\text { Abd Aziz, } \\
2020 \text { [92] }\end{array}$ & Kuala Lumpur & $\begin{array}{l}\text { Not } \\
\text { stated, } \\
\text { ethics } \\
\text { approved } \\
\text { in } 2018\end{array}$ & 60 , women & $\begin{array}{l}87 \% \\
\text { Malay } \\
7 \% \\
\text { Chinese } \\
5 \% \\
\text { Indian }\end{array}$ & 0 & ELISA & $\begin{array}{l}6,<30 \text { deficiency } \\
34,30-50 \\
\text { insufficiency }\end{array}$ \\
\hline $\begin{array}{l}\text { Arumugam, } \\
2020 \text { [93] }\end{array}$ & Kuala Lumpur & $\begin{array}{l}\text { June } 2014 \\
\text { to } \\
\text { February } \\
2015\end{array}$ & $\begin{array}{l}38, \text { controls for } \\
\text { cases (atopic } \\
\text { dermatitis) }\end{array}$ & $\begin{array}{l}\text { Not } \\
\text { reported }\end{array}$ & 36.8 & ECLIA & $\begin{array}{l}1,<30 \text { deficient } \\
22,30-50 \\
\text { insufficient }\end{array}$ \\
\hline $\begin{array}{l}\text { Chua, } 2020 \\
{[46]^{\star}}\end{array}$ & $\begin{array}{l}\text { Krau Wildlife } \\
\text { Reserve, Pahang }\end{array}$ & $\begin{array}{l}\text { Not } \\
\text { reported }\end{array}$ & $\begin{array}{l}555 \text { indigenous } \\
\text { adults (Orang Asli) }\end{array}$ & $\begin{array}{l}\text { Not } \\
\text { reported }\end{array}$ & 29.5 & ECLIA & $\begin{array}{l}8,<50 \text { deficient } \\
138,50-75 \\
\text { insufficient }\end{array}$ \\
\hline $\begin{array}{l}\text { Ismail, } 2020 \\
\text { [94] }\end{array}$ & Kuala Lumpur & $\begin{array}{l}\text { Not } \\
\text { reported }\end{array}$ & $\begin{array}{l}78 \text { pregnant } \\
\text { women }\end{array}$ & $\begin{array}{l}77 \% \\
\text { Malay } \\
15.4 \% \\
\text { Chinese } \\
5.1 \% \\
\text { Indian } \\
2.5 \% \\
\text { Others }\end{array}$ & 0 & ECLIA & $\begin{array}{l}27,<30 \text { deficient } \\
36,30-50 \\
\text { inadequate }\end{array}$ \\
\hline $\begin{array}{l}\text { Leiu, } 2020 \\
\text { [95] }\end{array}$ & $\begin{array}{l}\text { Kuala Lumpur } \\
\text { and Selangor. }\end{array}$ & $\begin{array}{l}\text { Not } \\
\text { reported }\end{array}$ & $\begin{array}{l}214 \text { post- } \\
\text { menopausal } \\
\text { Chinese women }\end{array}$ & $\begin{array}{l}100 \% \\
\text { Chinese }\end{array}$ & 0 & CLIA & $\begin{array}{l}71,<30 \text { deficient } \\
106,30-50 \\
\text { insufficient }\end{array}$ \\
\hline $\begin{array}{l}\text { Ismail TST, } \\
2020 \text { [96] }\end{array}$ & Kelantan & $\begin{array}{l}\text { August } \\
2017 \text { to } \\
\text { October } \\
2017\end{array}$ & $\begin{array}{l}126, \text { healthy } \\
\text { volunteers }\end{array}$ & $\begin{array}{l}100 \% \\
\text { Malay }\end{array}$ & 43.7 & CLIA & $\begin{array}{l}92,<30 \text { deficient } \\
12,30-50 \\
\text { insufficient }\end{array}$ \\
\hline $\begin{array}{l}\text { Woon, } 2020 \\
\text { [53] }\end{array}$ & $\begin{array}{l}\text { Kuala Lumpur } \\
\text { and Selangor }\end{array}$ & $\begin{array}{l}\text { November } \\
2016 \text { and } \\
\text { January } \\
2018\end{array}$ & 535 , late pregnancy & $\begin{array}{l}\text { Not } \\
\text { reported }\end{array}$ & 0 & CLIA & $\begin{array}{l}227,<30 \\
\text { deficient }\end{array}$ \\
\hline $\begin{array}{l}\text { Aris, } 2020 \\
{[26]}\end{array}$ & Kelantan & $\begin{array}{l}\text { May to } \\
\text { June } 2012\end{array}$ & $\begin{array}{l}119 \text { indoor workers, } \\
119 \text { outdoor } \\
\text { workers }\end{array}$ & $\begin{array}{l}100 \% \\
\text { Malay }\end{array}$ & $\begin{array}{l}31 \\
\text { (indoor) } \\
93.3 \\
\text { (outdoor) }\end{array}$ & ECLIA & $\begin{array}{l}64,<50 \text { deficient } \\
46,50-75 \\
\text { insufficient }\end{array}$ \\
\hline $\begin{array}{l}\text { Hussain S, } \\
2020[54]\end{array}$ & Kelantan & $\begin{array}{l}\text { Not } \\
\text { stated, } \\
\text { ethics } \\
\text { approved } \\
\text { in } 2012\end{array}$ & $\begin{array}{l}\text { 361, adolescents } \\
\text { from } 10 \text { schools }\end{array}$ & $\begin{array}{l}85 \% \\
\text { Malay } \\
15 \% \\
\text { Chinese }\end{array}$ & 37.1 & ECLIA & $\begin{array}{l}59,<30 \\
\text { deficiency }\end{array}$ \\
\hline $\begin{array}{l}\text { Chee WSS, } \\
2021 \text { [97] }\end{array}$ & Kuala Lumpur & $\begin{array}{l}\text { August } \\
2017 \text { to } \\
\text { August } \\
2019\end{array}$ & $\begin{array}{l}243,9 \text { - to } 11 \text {-year- } \\
\text { olds }\end{array}$ & $\begin{array}{l}90.5 \% \\
\text { Malay } \\
9.5 \% \\
\text { Indian }\end{array}$ & 52.3 & LC-MS/MS & $\begin{array}{l}46,<30 \text { deficient } \\
123,<50 \\
\text { inadequate }\end{array}$ \\
\hline $\begin{array}{l}\text { Mustapa } \\
\text { Kamal } \\
\text { Basha, } 2021 \\
{[52]}\end{array}$ & Kuala Lumpur & $\begin{array}{l}\text { November } \\
2017 \text { to } \\
\text { March } \\
2019\end{array}$ & $\begin{array}{l}179 \text {, longitudinal } \\
\text { study of pregnant } \\
\text { women }\end{array}$ & $\begin{array}{l}78 \% \\
\text { Malay } \\
13.6 \% \\
\text { Chinese } \\
6.8 \% \\
\text { Indian } \\
1.7 \% \\
\text { others }\end{array}$ & 0 & HPLC & $\begin{array}{l}161,<50 \\
\text { deficient }\end{array}$ \\
\hline
\end{tabular}


* Excluded from meta-analysis, HPLC high-performance liquid chromatography, $L C-M S / M S$ liquid chromatography with tandem mass spectrometry, ECLIA electrochemiluminescence immunoassay, ELISA enzyme-linked immunosorbent assay, CLIA chemiluminescent immunoassay

\begin{tabular}{|c|c|c|c|}
\hline & \multirow[t]{2}{*}{ Geographical area } & \multicolumn{2}{|l|}{ Prevalence, \% } \\
\hline & & Cut-off of $<25 \mathrm{nmol} / \mathrm{L}$ or $<30 \mathrm{nmol} / \mathrm{L}$ & Cut-off of $<50 \mathrm{nmol} / \mathrm{L}$ \\
\hline Hilger et al (2014) [59] & Global & $7 \%$ & $37 \%$ \\
\hline Herrick et al (2019) [60] & USA & $5 \%$ & $18 \%$ \\
\hline Cashman et al (2016) [61] & EU countries (adults) & $13 \%$ & $40 \%$ \\
\hline Arabi et al (2010) [29] & Iran and Jordan & $50 \%$ & $90 \%$ \\
\hline Durazo-Arvizu et al (2014) [62] & Ghana and Seychelles & $<1 \%$ & $<7 \%$ \\
\hline Mogire et al (2019) [63] & African continent & $18 \%$ & $34 \%$ \\
\hline Zhang et al (2013) [64] & Mainland China & Around $37 \%$ & Around $72 \%$ \\
\hline Liu et al (2021) [58] & Mainland China & $\begin{array}{l}20.7 \% \text { (Adults) } \\
23.0 \% \text { (adolescents) }\end{array}$ & $\begin{array}{l}\text { 63.2\% (Adults) } \\
\text { 46.8\% (Adolescents) }\end{array}$ \\
\hline This study & Malaysia & $21 \%$ & $64 \%$ \\
\hline
\end{tabular}

\section{Figures}




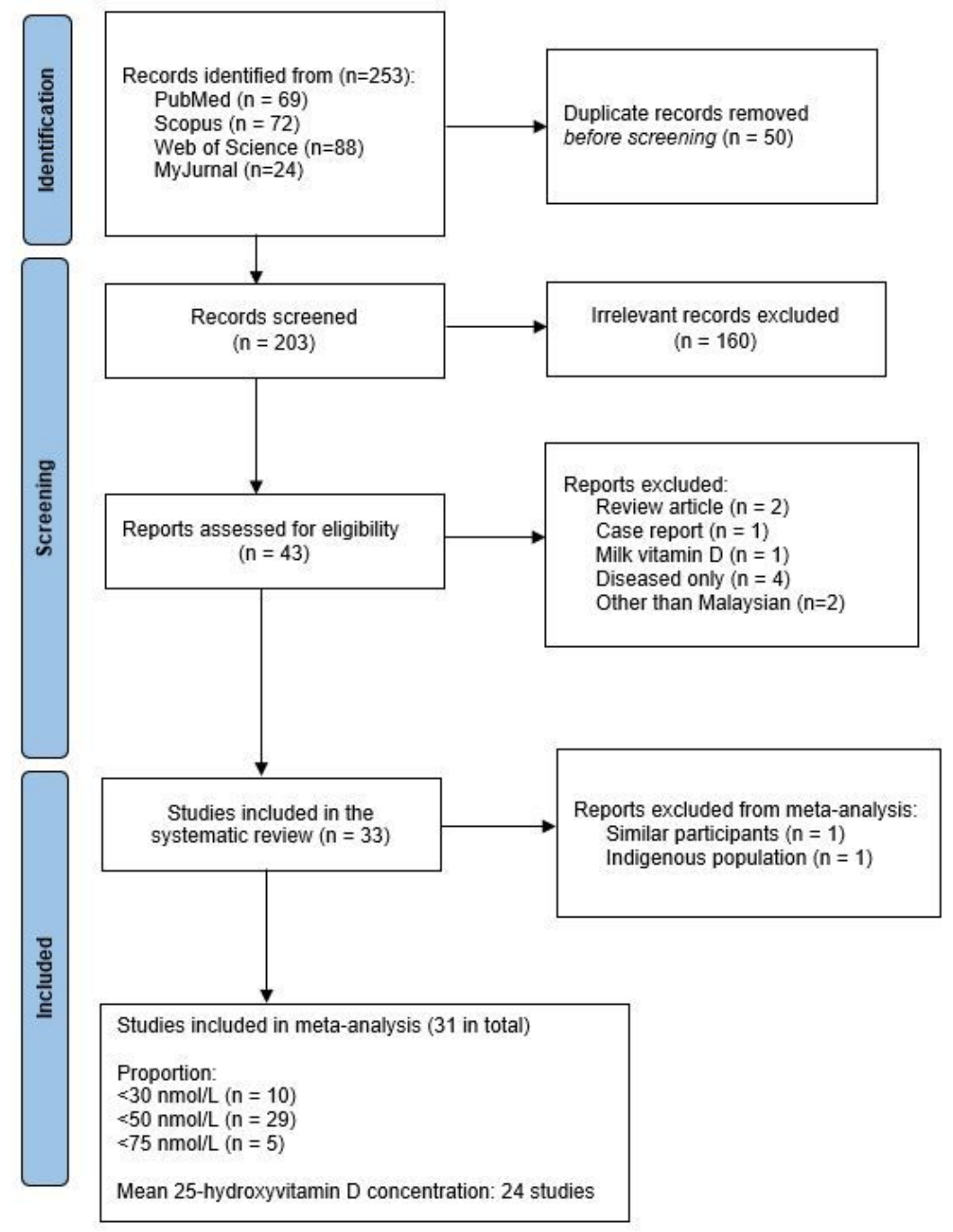

Figure 1

Flow-chart of study selection

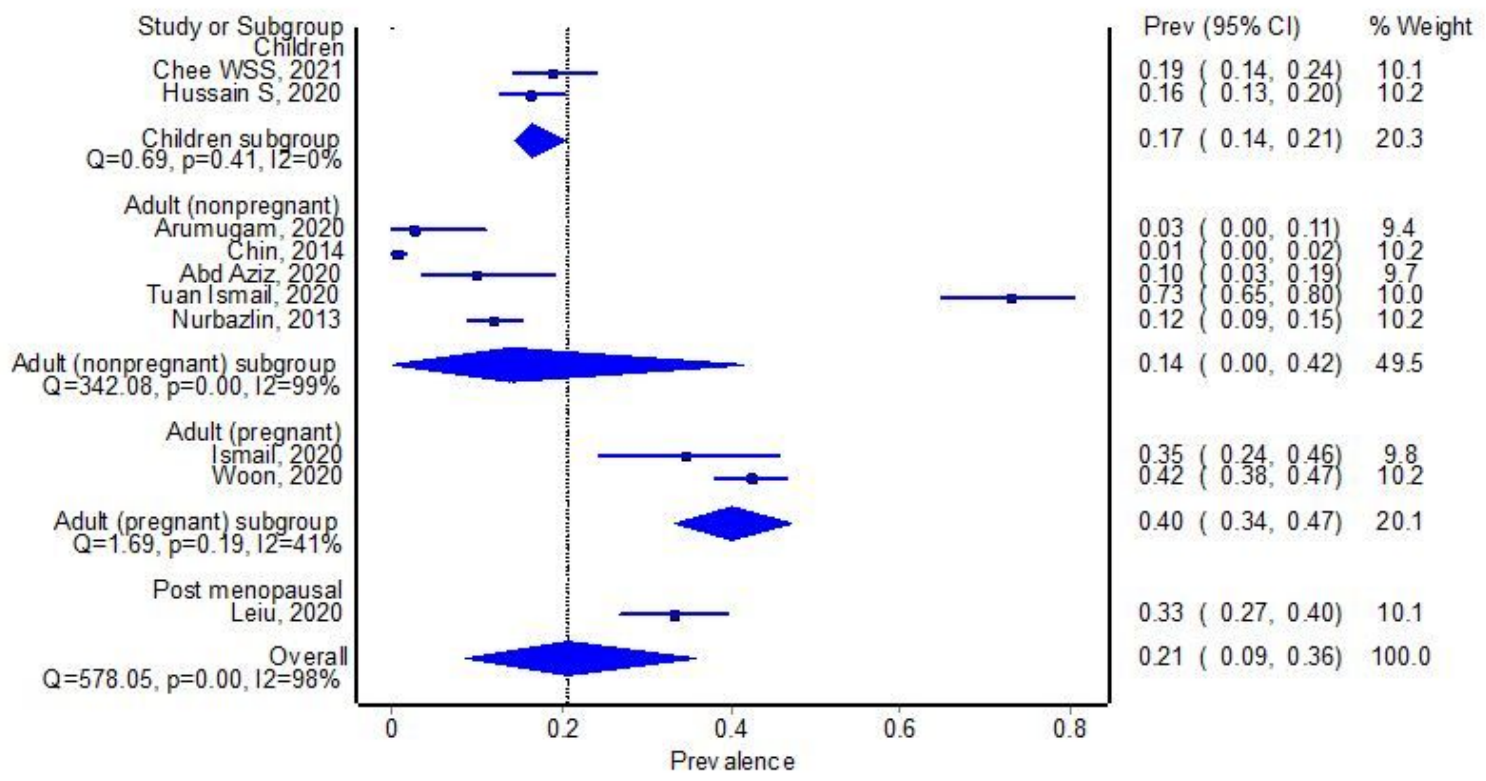

Figure 2 


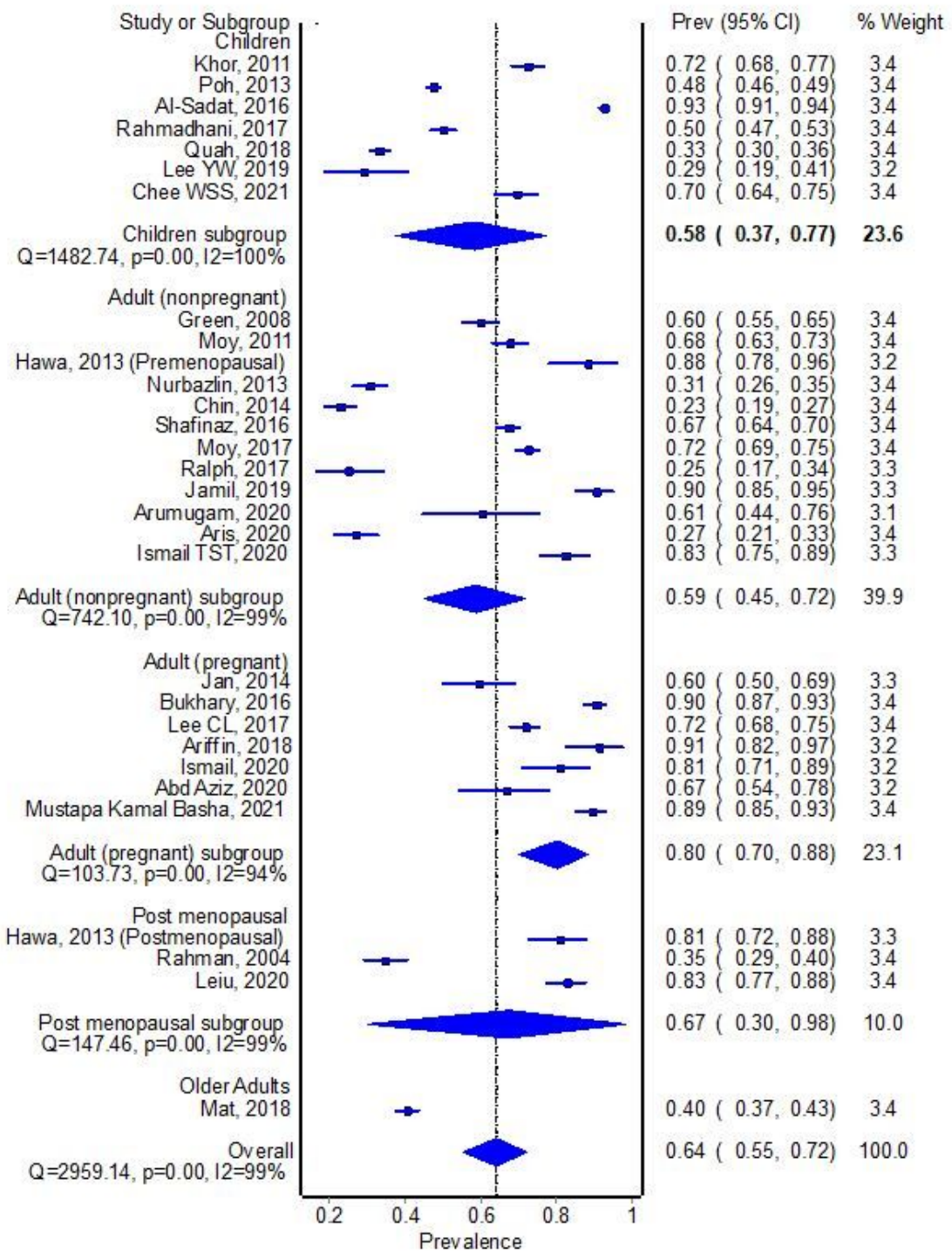

\section{Figure 3}

Pooled prevalence of $<50 \mathrm{nmol} / \mathrm{L} 25$-hydroxyvitamin D cut-off

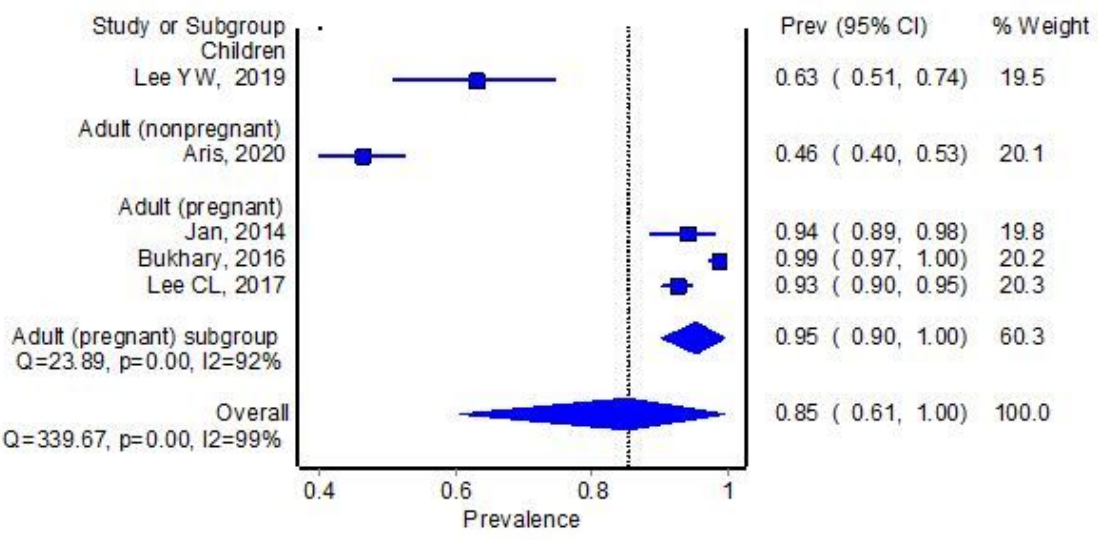

\section{Figure 4}

Pooled prevalence of $<75 \mathrm{nmol} / \mathrm{L}$ 25-hydroxyvitamin D cut-off 


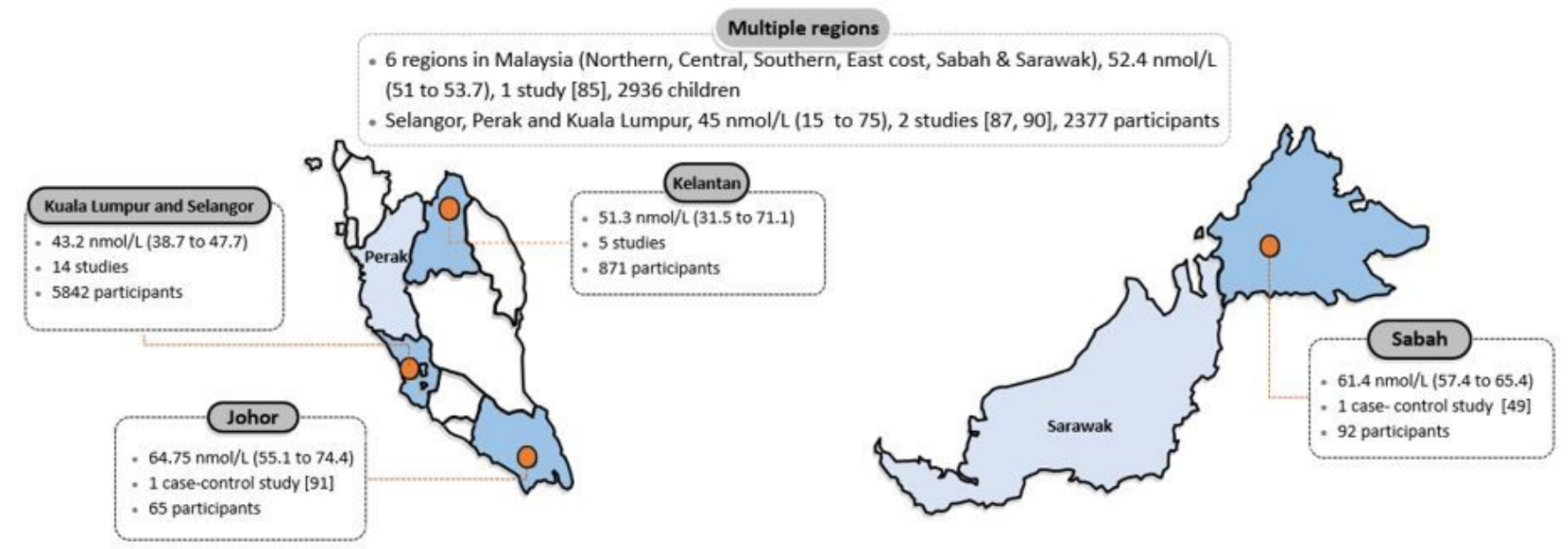

\section{Figure 5}

Mean 25-hydroxyvitamin D (25(OH)D) concentrations in Malaysia according to states. Data are the mean (95\% confidence interval) of 25(OH)D concentrations reported in studies done in each state. The $25(\mathrm{OH}) \mathrm{D}$ mean values were pooled if there were more than one study from a state and were computed only from studies that stated the mean (SD), or median and interquartile range or range.

\section{Supplementary Files}

This is a list of supplementary files associated with this preprint. Click to download.

- Appendix.docx 